\title{
Upper Eocene planktonic foraminifera from northern Saudi Arabia: implications for stratigraphic ranges
}

\author{
Bridget S. Wade ${ }^{1}$, Mohammed H. Aljahdali ${ }^{2}$, Yahya A. Mufrreh ${ }^{3}$, Abdullah M. Memesh ${ }^{4}$, \\ Salih A. AISoubhi ${ }^{3}$, and Iyad S. Zalmout ${ }^{3}$ \\ ${ }^{1}$ Department of Earth Sciences, University College London, Gower Street, London, WC1E 6BT, UK \\ ${ }^{2}$ Marine Geology Department, Faculty of Marine Sciences, \\ King Abdulaziz University, P.O. Box 80200, Jeddah 21589, Saudi Arabia \\ ${ }^{3}$ Saudi Geological Survey, Department of Sedimentary Geology, Jeddah, Saudi Arabia \\ ${ }^{4}$ Saudi Geological Survey, Department of Paleontology, Jeddah, Saudi Arabia
}

Correspondence: Bridget S. Wade (b.wade@ucl.ac.uk)

Received: 7 February 2021 - Revised: 20 August 2021 - Accepted: 29 August 2021 - Published: 28 September 2021

\begin{abstract}
The Rashrashiyah Formation of the Sirhan Basin in northern Saudi Arabia contains diverse assemblages of planktonic foraminifera. We examined the biostratigraphy, stratigraphic range and preservation of upper Eocene planktonic foraminifera. Assemblages are well-preserved and diverse, with 40 species and 11 genera. All samples are assigned to the Priabonian Globigerinatheka semiinvoluta Highest Occurrence Zone (E14), consistent with calcareous nannofossil biostratigraphy indicating Zone CNE17. Well-preserved planktonic foraminifera assemblages from the lower part of the upper Eocene are rare worldwide. Our study provides new insights into the stratigraphic ranges of many species. We find older (Zone E14) stratigraphic occurrences of several species of Globoturborotalita previously thought to have evolved in the latest Eocene (Zone E15, E16) or Oligocene; these include G. barbula, G. cancellata, G. gnaucki, G. pseudopraebulloides, and G. paracancellata. Older stratigraphic occurrences for Dentoglobigerina taci and Subbotina projecta are also found, and Globigerinatheka kugleri occurs at a younger stratigraphic level than previously proposed. Our revisions to stratigraphic ranges indicate that the late Eocene had a higher tropical-subtropical diversity of planktonic foraminifera than hitherto reported.
\end{abstract}

\section{Introduction}

Planktonic foraminifera are calcareous marine zooplankton. Their abundance and distinctive morphologies have left a long and valuable marine fossil record, making them ideal for studies in evolution, climate, and relationships between diversity and climate change. The diversity of planktonic foraminifera is high during the middle Eocene (Pearson et al., 2006; Aze et al., 2011; Fraass et al., 2015), but calcareous and siliceous zooplankton suffered extinction at the end of the Bartonian associated with the middle-late Eocene transition (MLET) (Wade, 2004; Kamikuri and Wade, 2012; Wade et al., 2012) and again across the Eocene-Oligocene transition (EOT) (Wade and Pearson, 2008; Moore and Kamikuri, 2012). However, to date there have been very few sections with well-preserved lower Priabonian (Zone E14) planktonic foraminifera assemblages that allow both the wall textures of specimens to be examined and the full diversity to be documented.

The term Konservat-Lagerstätte (Seilacher, 1970) is used to characterize exceptional preservation in the fossil record. The Paleogene sediments of coastal Tanzania contain remarkably well-preserved calcareous microfossils (Pearson et al., 2001, 2007; Wade and Pearson, 2008), and these were described as a microfossil Konservat-Lagerstätte by Bown et al. (2008). The development of a calcareous microfossil Konservat-Lagerstätte appears to be related to clay-rich sediments that have never been deeply buried (Bown et al., 2008). The clays act as a low-permeability and low-porosity medium, isolating microfossils from chemical and physical 
processes of diagenetic alteration. Evidence for exceptional preservation comes from taxonomic, morphological and geochemical data. Planktonic foraminifera appear translucent or glassy in reflected light, and their wall texture is smooth in scanning electron microscope (SEM) images. These assemblages are probably the nearest approximation to the original biodiversity, providing a unique snapshot of ancient ecosystems. Planktonic foraminifera preservation is important to reveal details of wall texture, imperative for classification and thus phylogeny (e.g., Hemleben and Olsson, 2006). As wall texture underpins genus and higher level taxonomy, only with high-quality preservation of all the morphological characteristics can comprehensive assessments of the full diversity be achieved. A lack of recrystallization and infilling allows delicate features to be observed, for example intact apertural "teeth" in dentoglobigerinids, the ability to detect spine holes and therefore distinguish spinose lineages (Pearson and Wade, 2015; Fayolle and Wade, 2021). It is common to observe a decrease in the preservation state of buried microfossils. In contrast to "glassy" preservation, recrystallized specimens appear chalky or white in reflected light. Diagenesis in planktonic foraminifera can involve overgrowth, changes in the test crystal structure at the micrometer scale, and/or infilling of the original test, all of which have significant implications for geochemical and taxonomic studies.

While the microfossil Lagerstätten preservation from Tanzania has led to important insights into the Eocene calcareous microfossil preservation (Bown et al., 2008), paleoecology and diversity (Wade and Pearson, 2008; Dunkley Jones et al., 2008), and paleoclimates (Pearson et al., 2001, 2007, 2008, 2009; Lear et al., 2008), Tanzania is not unique in offering such exceptional preservation. Other sites exist, though their records are not always as continuous (e.g., Alabama, Miller et al., 2008; Ocean Drilling Program Site 647, Firth et al., 2013; Integrated Ocean Drilling Program Expedition 342 , Norris et al., 2014). Paleogene sites that contain excellently preserved microfossils provide significant insights into planktonic foraminiferal taxonomy and evolutionary snapshots into planktonic foraminiferal history. High-resolution SEM analysis of well-preserved planktonic foraminifera can reveal primary wall fabrics that have not previously been observed. Detailed taxonomic studies are critical to understanding the phylogeny and evolution of planktonic foraminifera through the late Eocene. The Tanzania cores, however, do not have recovery in the lower part of the upper Eocene (Priabonian), as such planktonic foraminifera taxonomic work focused on the middle Eocene (Pearson et al., 2006) and EOT (Pearson and Wade, 2015). Here we present new biostratigraphic results and taxonomic insights from well-preserved material from Saudi Arabia.

The Paleogene Planktonic Foraminifera Working Group described 14 new taxa as part of the Atlas of Oligocene Planktonic Foraminifera (Wade et al., 2018a). These included four new species described from the late Eocene and early Oligocene: Globigerina archaeobulloides Hem- leben and Olsson, Globoturborotalita paracancellata Olsson and Hemleben, Globoturborotalita pseudopraebulloides Olsson and Hemleben, and Subbotina projecta Olsson, Pearson and Wade. However, the early stratigraphic ranges of these species were not well constrained, requiring examination of well-preserved upper Eocene sediments to determine if these species were present. Our new study section with well-preserved planktonic foraminifera from Saudi Arabia allows us to document the presence or absence of these newly described species and provide constraints to the stratigraphic ranges.

The calcareous nannofossil biostratigraphy from the upper Eocene Rashrashiyah Formation in northern Saudi Arabia was recently published in Aljahdali et al. (2020). Here we present a pilot investigation of the planktonic foraminifera results for the same section. Whilst our sample set is limited, we present 96 stacked light microscope and SEM images of the diverse late Eocene assemblages. Our taxonomic investigations utilize the Atlas of Oligocene Planktonic Foraminifera (Wade et al., 2018a), and we find several species recently described in that volume but not previously recorded outside the Oligocene. Planktonic foraminifera results are integrated with previous calcareous nannofossil records, and the implications for planktonic foraminiferal stratigraphic ranges are discussed.

\section{Materials and methods}

\subsection{Geological setting}

The Sirhan (also known as the Azraq-Sirhan) Basin is a northwest-southeast-oriented, regional antisynclinal structure, located in the northern Arabian Peninsula (Fig. 1). It is part of the Syrian Arc System (Guiraud et al., 2001) where subsidence in the early Paleogene Tethyan seafloor resulted in deposition of carbonate and mixed sediments (Al-Rawi, 2014). The Rashrashiyah Formation crops out in the eastern flank of the Sirhan Basin $\left(31.46^{\circ} \mathrm{N}, 37.36^{\circ} \mathrm{E}\right)$ and consists of upper Eocene chalks, claystone and limestone (Meissner et al., 1990; Halawani, 2001; Aljahdali et al., 2020) (Figs. 2 and 3 ). We investigated the uppermost $10 \mathrm{~m}$ of the Rashrashiyah Formation. Five samples were obtained, with a resolution of one sample per meter, and assigned the prefix A-E (Figs. 2 and 3, Table 1). To provide stratigraphic constraints, an additional sample (Sample F) was taken close to the upper contact boundary between Rashrashiyah and Sirhan formations. The sampling is the same as in Aljahdali et al. (2020) for calcareous nannofossils.

\subsection{Sample preparation}

For planktonic foraminiferal analysis, samples were washed over a $63 \mu \mathrm{m}$ sieve and oven-dried at $<40^{\circ} \mathrm{C}$. The dried sample was separated into $>425,355-425,250-355,150$ 250 and $63-150 \mu \mathrm{m}$ size fractions, and each size fraction was 


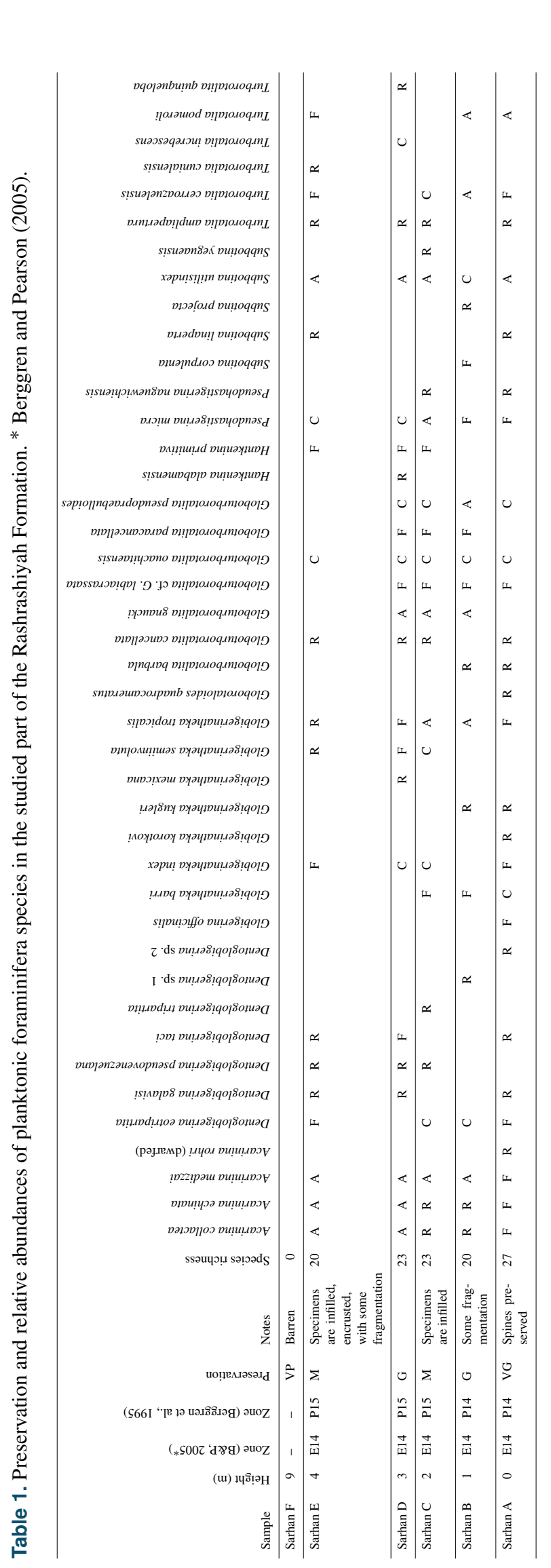

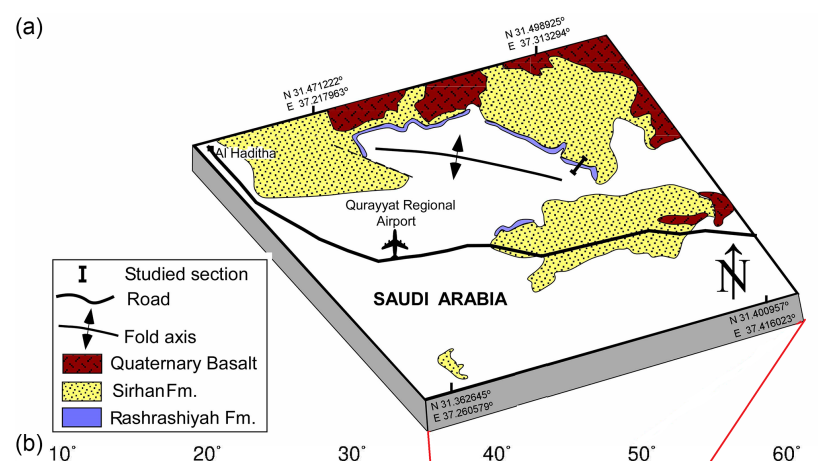

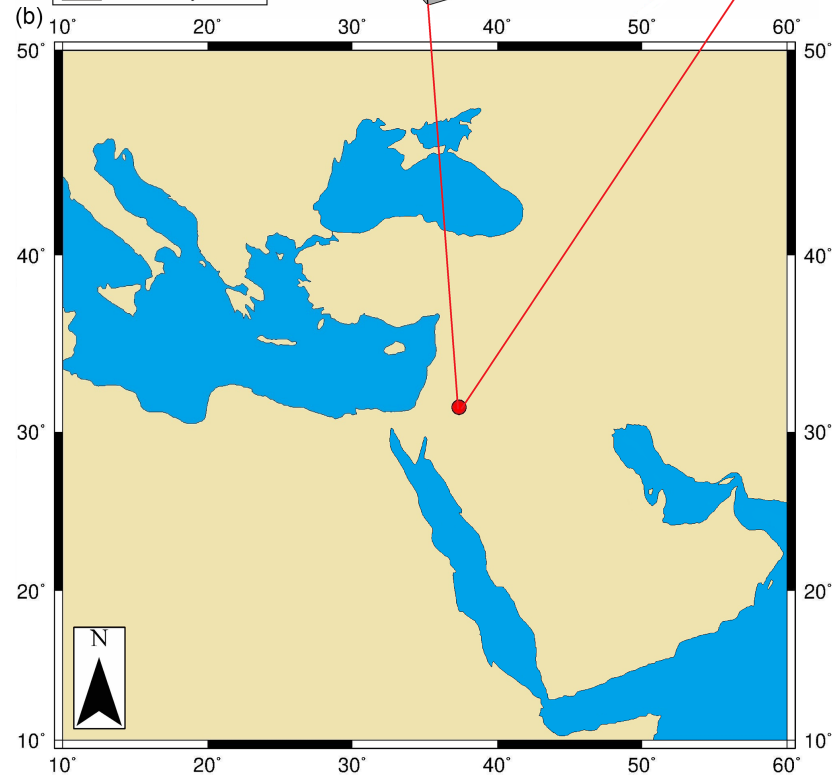

Figure 1. Map showing location of the studied section and geological contexts of the Rashrashiyah Formation in the north-western part of Saudi Arabia. (a) Geological map of the Qurayyat area showing the extension of the Rashrashiyah Formation around the Qurayyat Regional Airport (modified after Aljahdali et al., 2020, and Wallace et al., 1994). (b) Location of the Rashrashiyah Formation exposures in north-western Saudi Arabia (map produced using Ocean Drilling Stratigraphic Network https://www.odsn.de/, last access: 17 August 2021).

examined under the light microscope. Following the taxonomy of Pearson et al. (2006), Pearson and Wade (2015), and Wade et al. (2018a), the abundance of each species was semiqualitatively assessed as follows: A - abundant; C - common; F - few; R - rare (Table 1). Preservation was assessed as VG (very good), where specimens are glassy under the light microscope with no infilling; $G$ (good), where specimens are semi-translucent and with no infilling; $M$ (moderate), where specimens are recrystallized and the test walls are opaque, and VP (very poor), where specimens are fragmented, opaque and infilled.

Selected specimens were picked for $z$-stacked light microscope and SEM imaging. A $z$-stacking light microscope was used to take images in three views (umbilical, edge and spiral view). For SEM imaging specimens were placed on stubs 


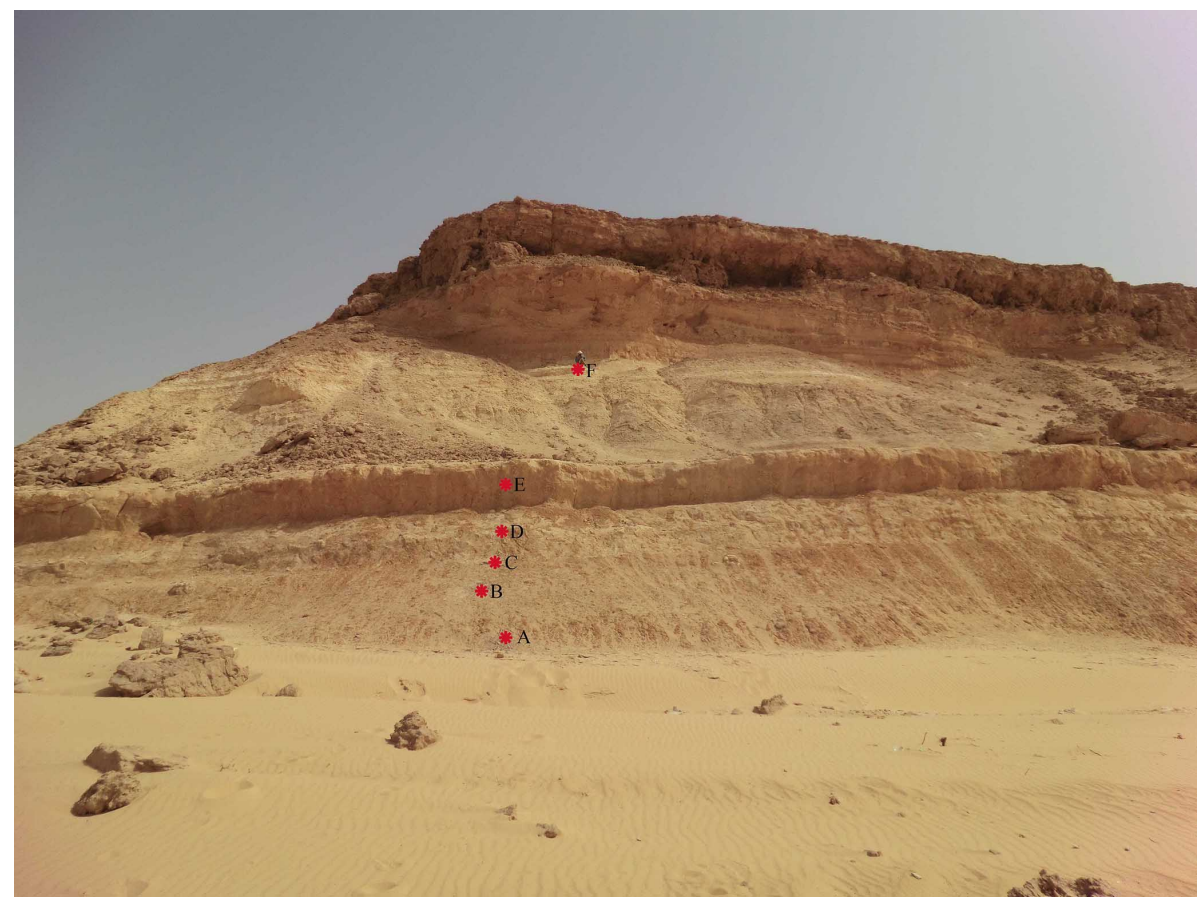

Figure 2. Photograph of the sampled levels of the locally exposed Rashrashiyah Formation section near the Saudi-Jordanian boarders. Letters A-F represent sampling levels (photo courtesy of the Saudi Geological Survey).

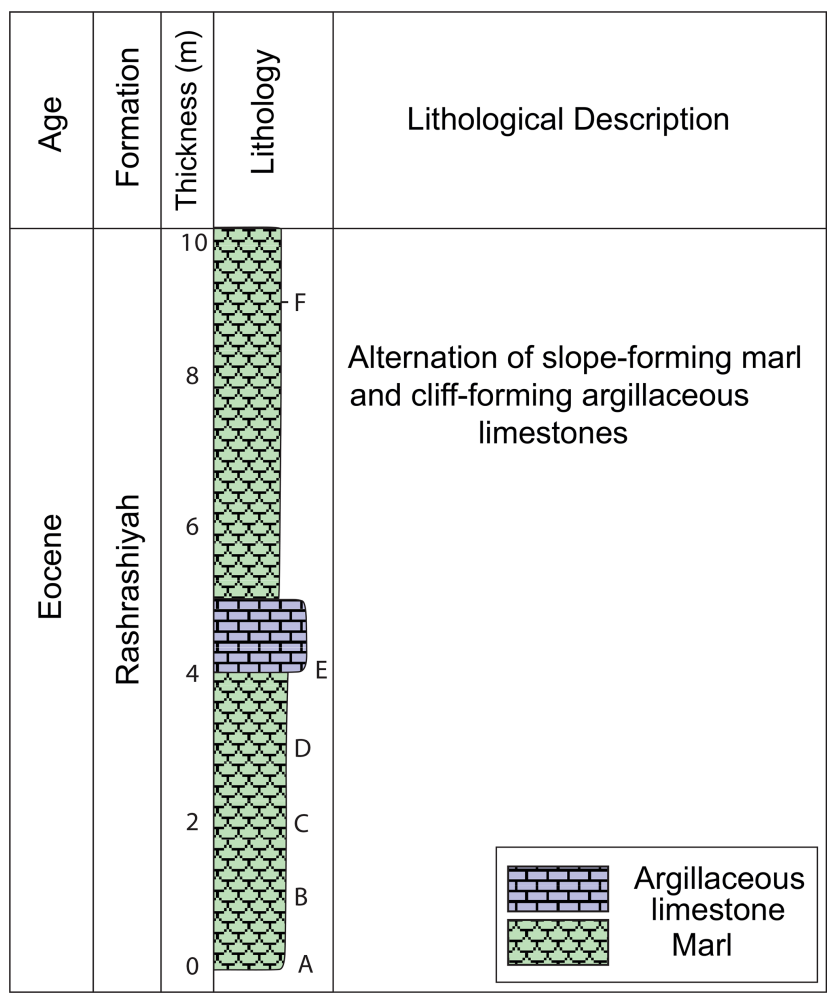

Figure 3. Lithology of the studied Rashrashiyah Formation section. Letters A-F represent sample levels. using double-sided tape. Each stub was coated in an argon and gold atmosphere using a sputter coater. The illustrated specimens (Figs. 4-9) are deposited in the Natural History Museum, London, UK (NHMUK PM PF 75192-75251).

\section{Results}

Samples A-E contain abundant and diverse assemblages of planktonic foraminifera, with a total of 40 species and 11 genera (Table 1). The assemblages are characteristic of tropical-subtropical pelagic settings, with common and abundant species of Globigerinatheka, Globoturborotalita, small $(<250 \mu \mathrm{m})$ Acarinina, Dentoglobigerina, Subbotina, Turborotalia, Hantkenina and Pseudohastigerina. Globigerina officinalis, Globorotaloides quadrocameratus, and Turborotalita quinqueloba are also present (Table 1, Figs. 4-10). Sample F was barren.

Preservation in Samples A to E ranges from very good to moderate. There is some iron staining throughout. We use the zonal scheme of Berggren and Pearson (2005) and Wade et al. (2011). The absence of the large muricate taxa and the presence of Globigerinatheka semiinvoluta in Samples $\mathrm{C}, \mathrm{D}$ and $\mathrm{E}$ indicate that the section can be assigned to the planktonic foraminifera Globigerinatheka semiinvoluta HOZ (Zone E14; Berggren and Pearson, 2005; Wade et al., 2011). 


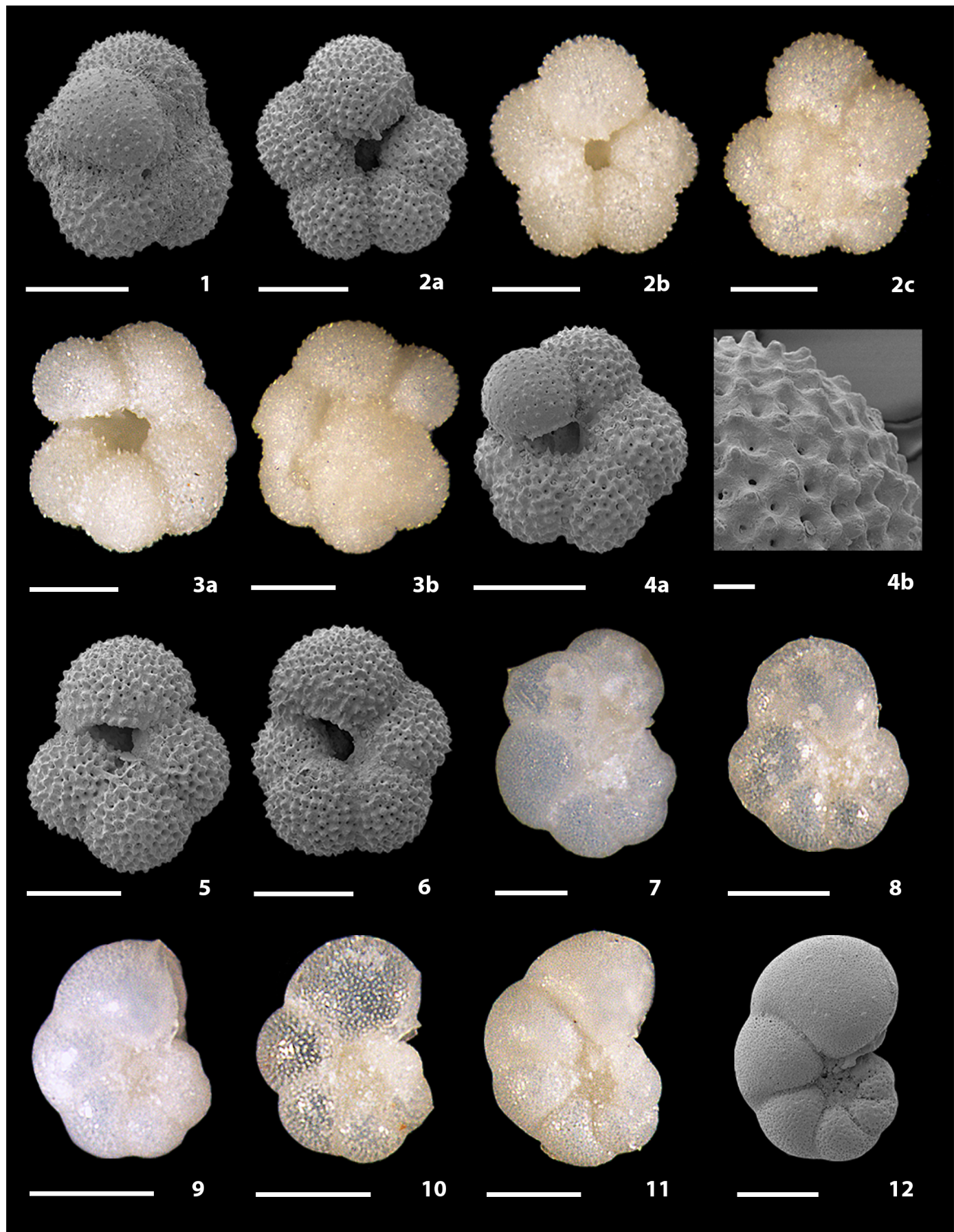

Figure 4. Light microscope and SEM images of Acarinina and Pseudohastigerina from the Rashrashiyah Formation: (1) NHMUK PM PF 75192 Acarinina echinata, Sample C; (2a, 2b, 2c) NHMUK PM PF 75193 Acarinina medizzai, Sample A; (3a, 3b) NHMUK PM PF 75194 Acarinina medizzai, Sample B; (4a, 4b) NHMUK PM PF 75195 Acarinina medizzai, Sample B; (5) NHMUK PM PF 75196 Acarinina medizzai, Sample D; (6) NHMUK PM PF 75197 Acarinina medizzai, Sample A; (7) NHMUK PM PF 75231 Pseudohastigerina naguewichiensis, Sample C; (8) NHMUK PM PF 75232 Pseudohastigerina naguewichiensis, Sample A; (9) NHMUK PM PF 75233 Pseudohastigerina micra, Sample B; (10) NHMUK PM PF 75209 Pseudohastigerina micra, Sample A; (11) NHMUK PM PF 75210 Pseudohastigerina micra,

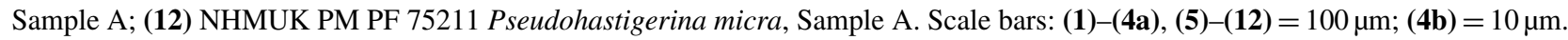




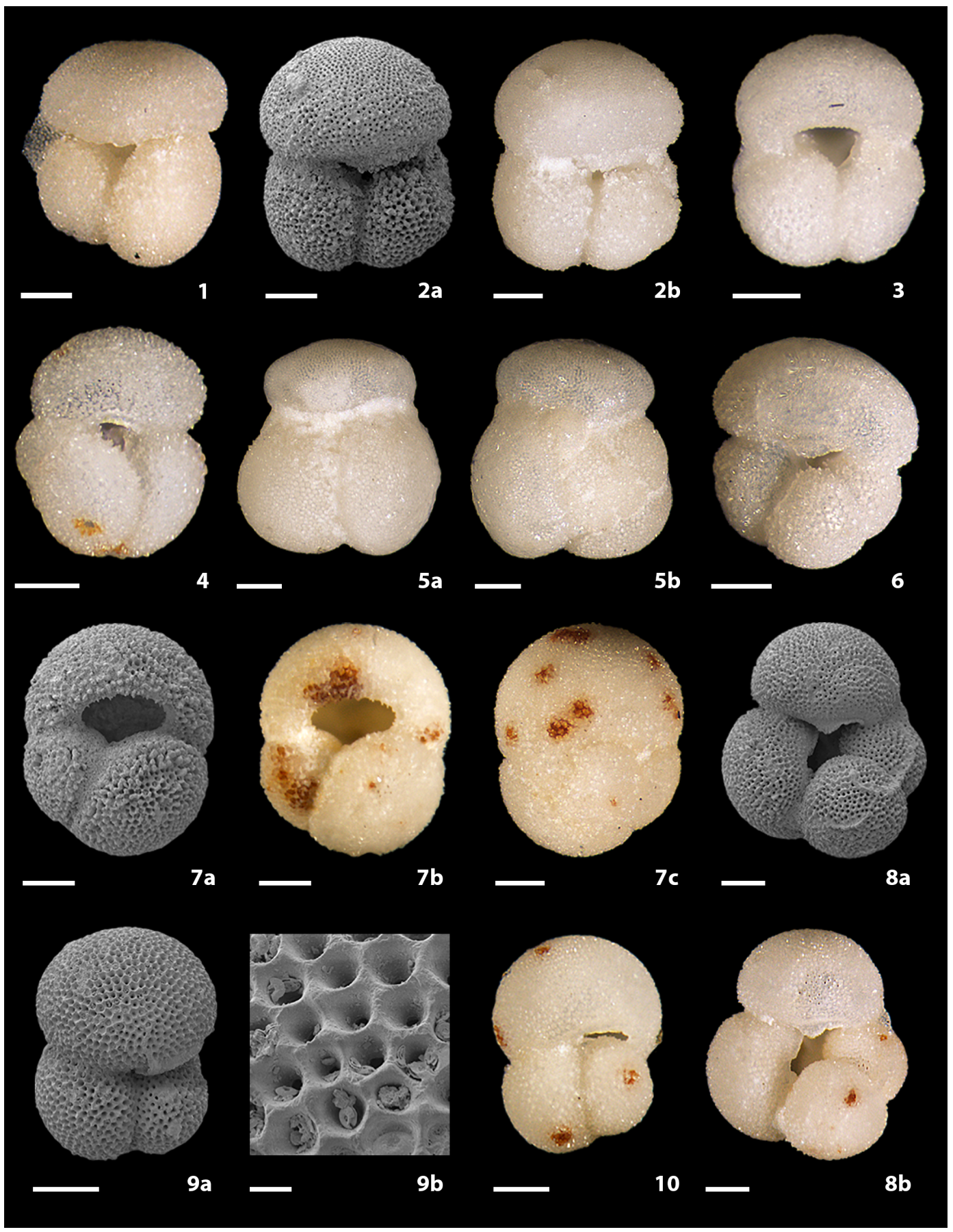

Figure 5. Light microscope and SEM images of Dentoglobigerina and Subbotina from the Rashrashiyah Formation: (1) NHMUK PM PF 75204 Dentoglobigerina eotripartita, Sample B; (2a, 2b) NHMUK PM PF 75205 Dentoglobigerina galavisi, Sample D; (3) NHMUK PM PF 75206 Dentoglobigerina taci, Sample D; (4) NHMUK PM PF 75234 Dentoglobigerina taci, Sample A; (5a, 5b) NHMUK PM PF 75235 Dentoglobigerina tripartita, Sample C; (6) NHMUK PM PF 75208 Dentoglobigerina sp. 1, Sample B; (7a, 7b, 7c) NHMUK PM PF 75207 Dentoglobigerina sp. 2, Sample A; (8a, 8b) NHMUK PM PF 75212 Subbotina projecta, Sample B; (9a, 9b) NHMUK PM PF 75213 Subbotina utilisindex, Sample B; (10) NHMUK PM PF 75214 Subbotina linaperta, Sample A. Scale bars: (1)-(9a), (10)=100 $\mu$ m; (9b) $=10 \mu \mathrm{m}$. 


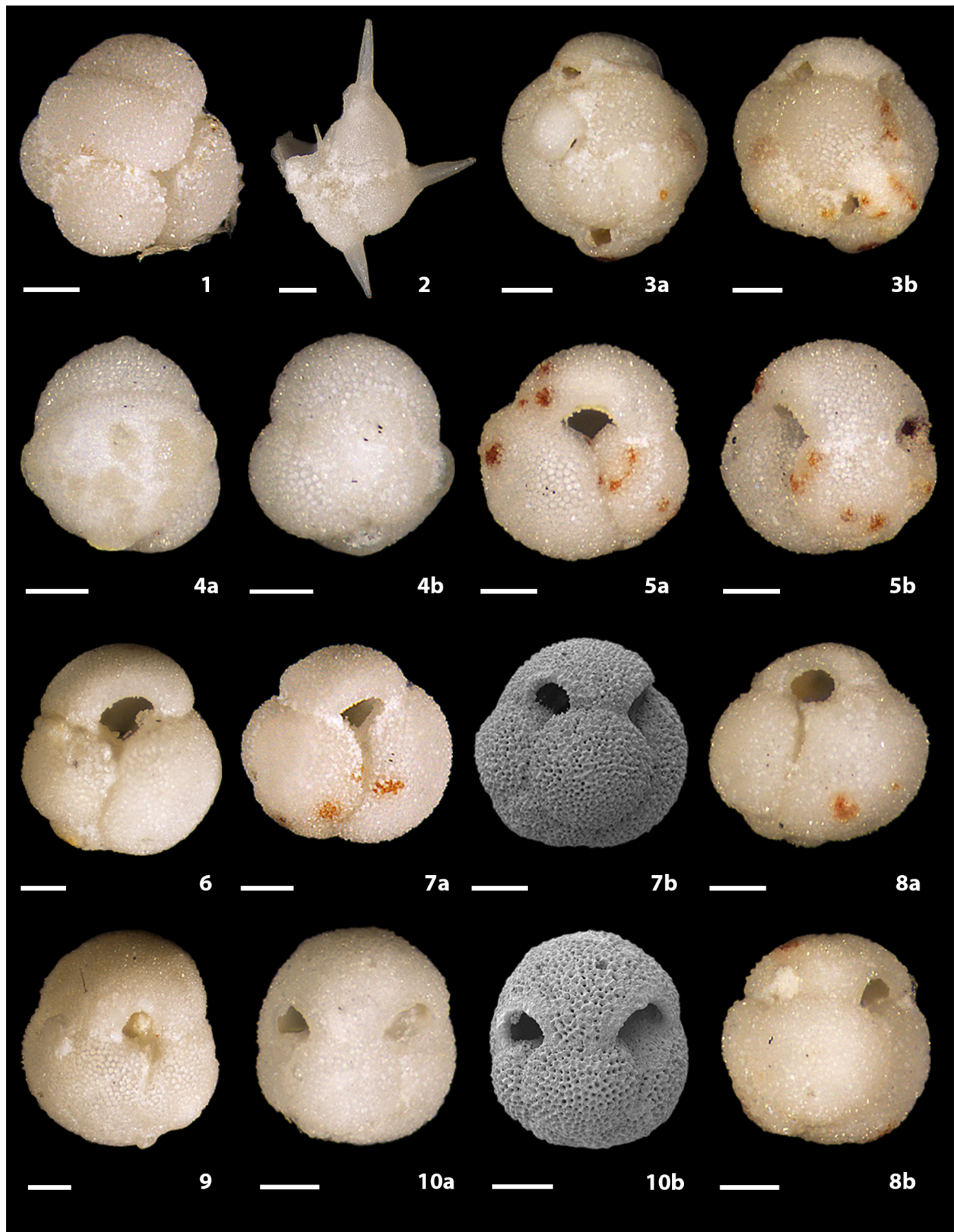

Figure 6. Light microscope and SEM images of Subbotina, Hantkenina and Globigerinatheka from the Rashrashiyah Formation: (1) NHMUK PM PF 75236 Subbotina corpulenta, Sample B; (2) NHMUK PM PF 75199 Hantkenina primitiva, Sample C; (3a, 3b) NHMUK PM PF 75237 Globigerinatheka barri, Sample A; (4a, 4b) NHMUK PM PF 75238 Globigerinatheka barri, Sample C; (5a, 5b) NHMUK PM PF 75239 Globigerinatheka index, Sample A; (6) NHMUK PM PF 75240 Globigerinatheka index, Sample D; (7a, 7b) NHMUK PM PF 75241 Globigerinatheka kugleri, Sample B; (8a, 8b) NHMUK PM PF 75242 Globigerinatheka kugleri, Sample A; (9) NHMUK PM PF 75243 Globigerinatheka mexicana, Sample D; (10a, 10b) NHMUK PM PF 75200 Globigerinatheka mexicana, Sample D. Scale bars: (1) $-(\mathbf{1 0 b})=100 \mu \mathrm{m}$. 


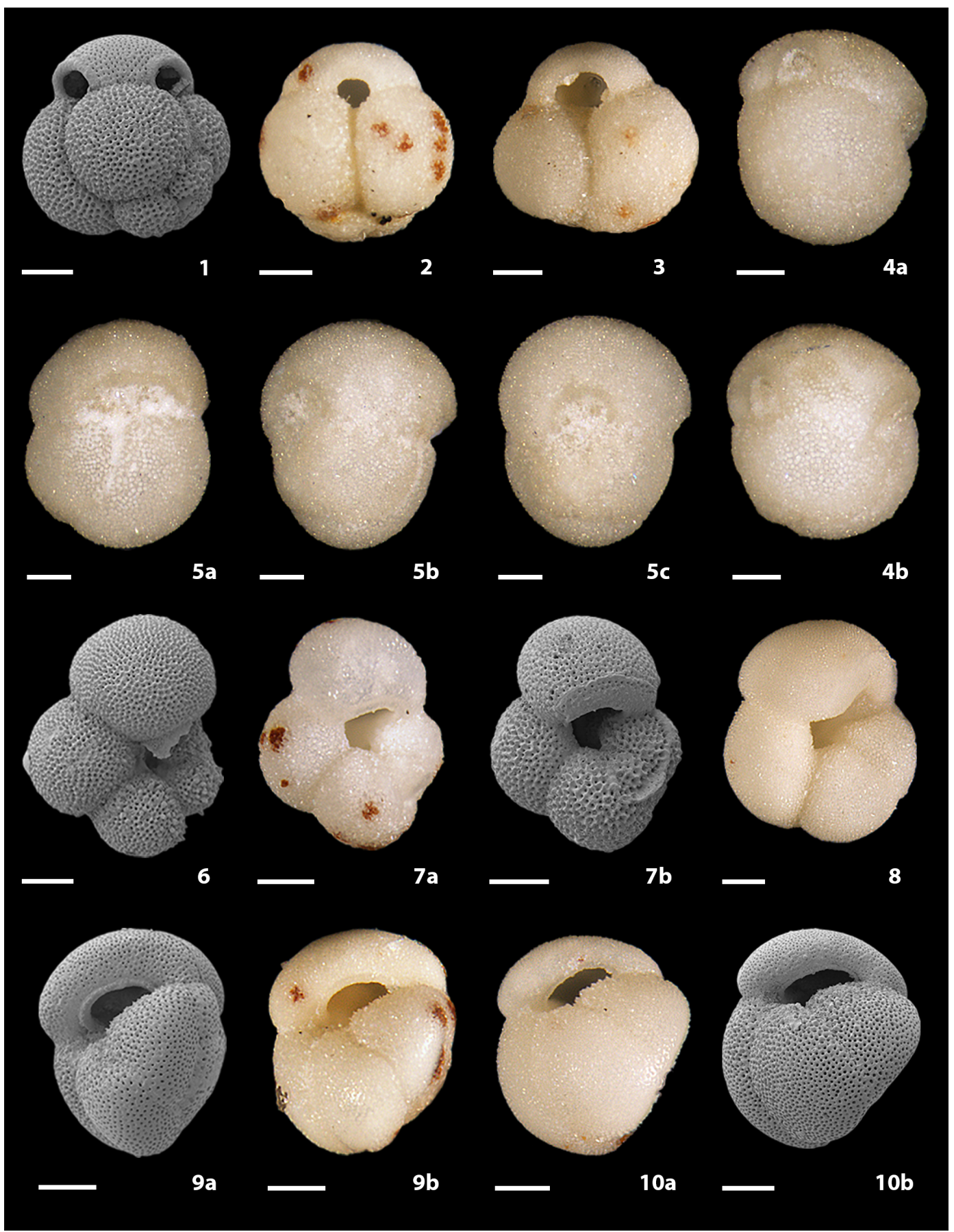

Figure 7. Light microscope and SEM images of Globigerinatheka, Globorotaloides and Turborotalia from the Rashrashiyah Formation: (1) NHMUK PM PF 75201 Globigerinatheka tropicalis, Sample B; (2) NHMUK PM PF 75202 Globigerinatheka tropicalis, Sample A; (3) NHMUK PM PF 75203 Globigerinatheka tropicalis, Sample A; (4a, 4b) NHMUK PM PF 75244 Globigerinatheka semiinvoluta, Sample C; (5a, 5b, 5c) NHMUK PM PF 75245 Globigerinatheka semiinvoluta, Sample C; (6) NHMUK PM PF 75198 Globorotaloides quadrocameratus, Sample A; (7a, 7b) NHMUK PM PF 75227 Turborotalia ampliapertura, Sample A; (8) NHMUK PM PF 75228 Turborotalia cerroazulensis, Sample B; (9a, 9b) NHMUK PM PF 75229 Turborotalia cerroazulensis, Sample A; (10a, 10b) NHMUK PM PF 75230 Turborotalia cerroazulensis, Sample B. Scale bars: $\mathbf{( 1 )}-(\mathbf{1 0 b})=100 \mu \mathrm{m}$. 


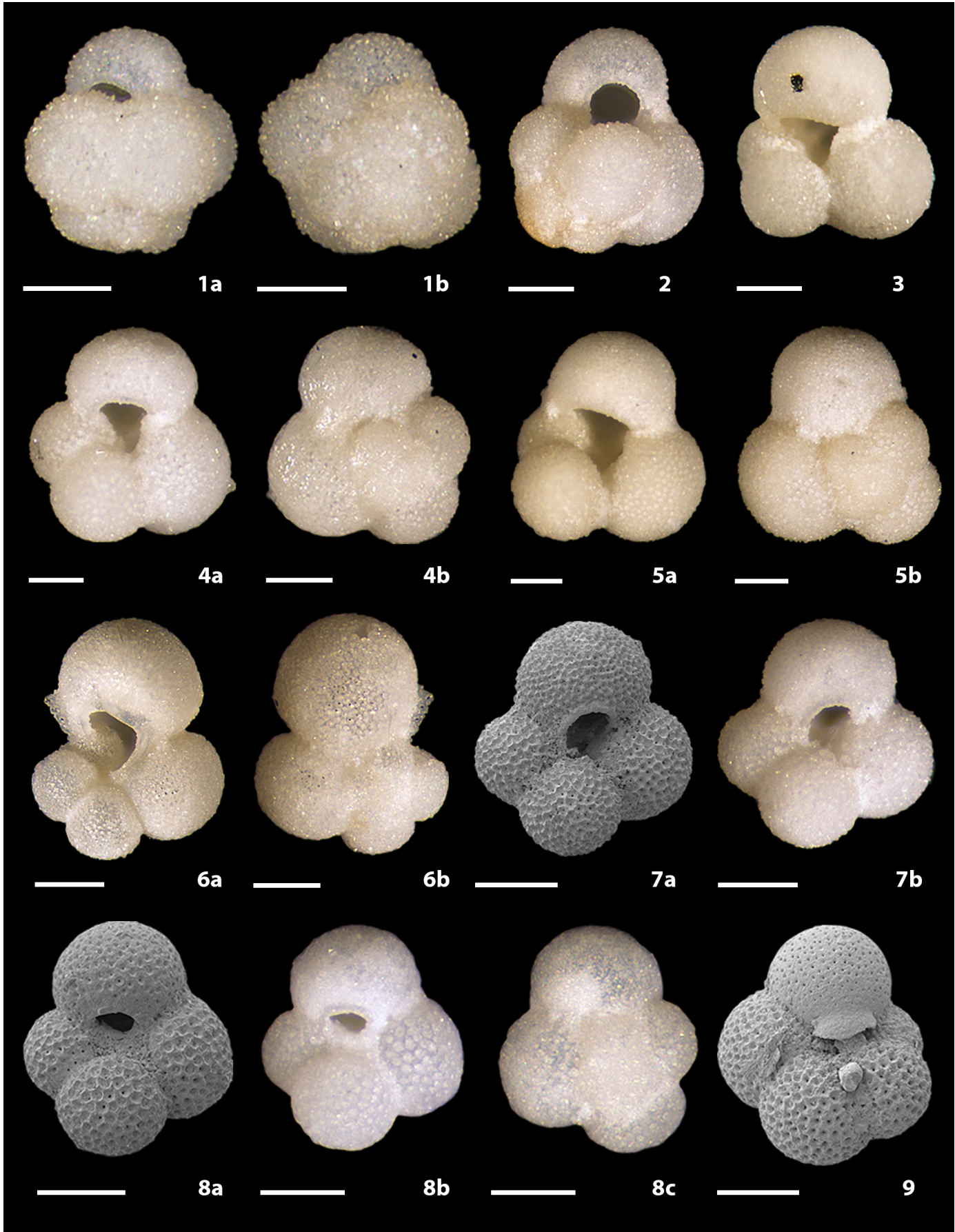

Figure 8. Light microscope and SEM images of Globoturborotalita and Turborotalita from the Rashrashiyah Formation: (1a, 1b) NHMUK PM PF 75248 Globoturborotalita barbula, Sample A; (2) NHMUK PM PF 75249 Globoturborotalita barbula, Sample B; (3) NHMUK PM PF 75250 Globoturborotalita cancellata, Sample A; (4a, 4b) NHMUK PM PF 75223 Globoturborotalita cancellata, Sample E; (5a, 5b) NHMUK PM PF 75224 Globoturborotalita cancellata, Sample D; (6a, 6b) NHMUK PM PF 75251 Globoturborotalita gnaucki, Sample B; (7a, 7b) NHMUK PM PF 75225 Globoturborotalita ouachitaensis, Sample C; (8a, 8b, 8c) NHMUK PM PF 75226 Globoturborotalita ouachitaensis, Sample C; (9) NHMUK PM PF 75222 Turborotalita quinqueloba, Sample D. Scale bars: (1)-(9)=100 $\mu$ m. 


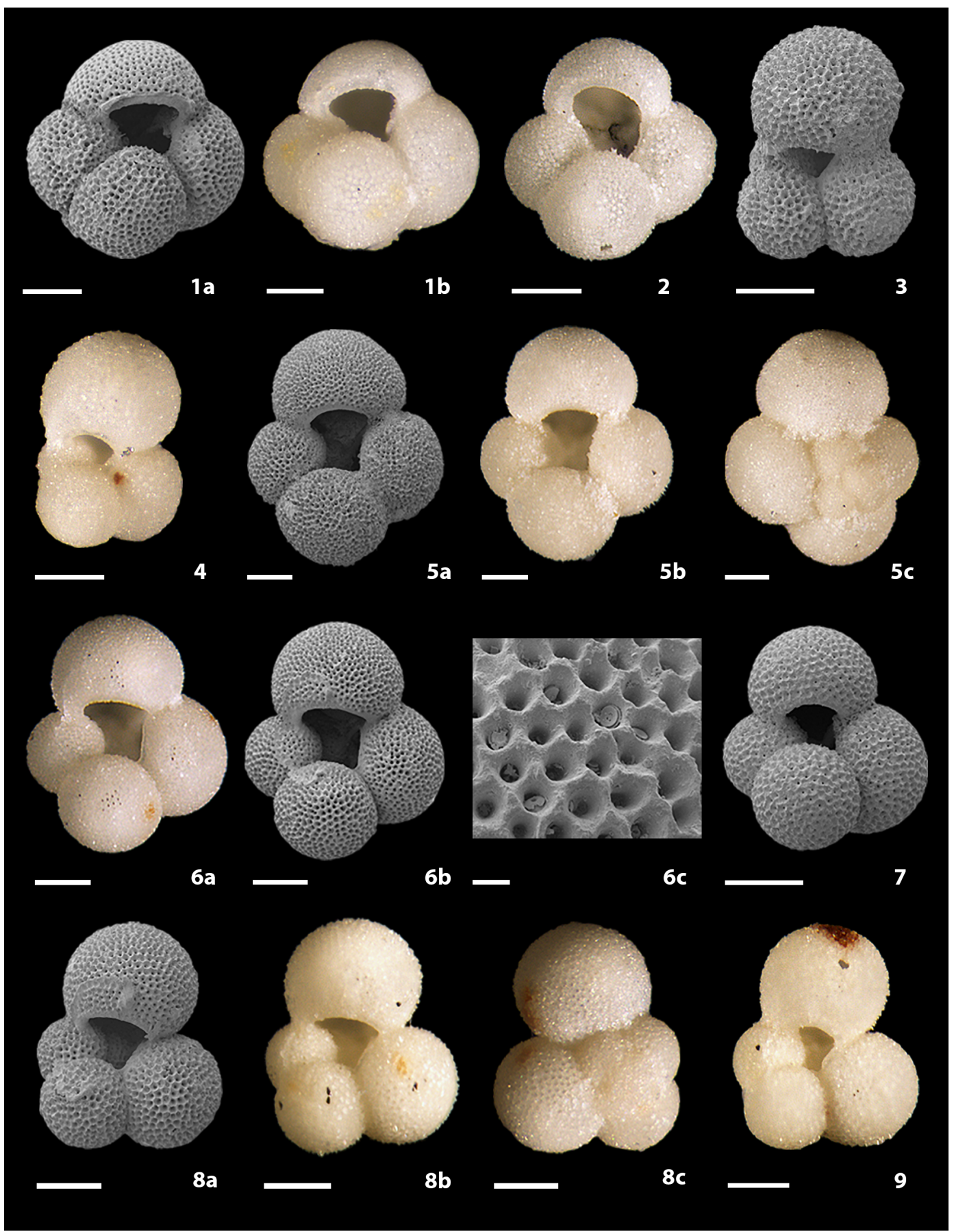

Figure 9. Light microscope and SEM images of Globoturborotalita from the Rashrashiyah Formation: (1a, 1b) NHMUK PM PF 75215 Globoturborotalita cf. G. labiacrassata, Sample D; (2) NHMUK PM PF 75216 Globoturborotalita cf. G. labiacrassata, Sample B; (3) NHMUK PM PF 75217 Globoturborotalita paracancellata, Sample D; (4) NHMUK PM PF 75246 Globoturborotalita paracancellata, Sample B; (5a, 5b, 5c) NHMUK PM PF 75219 Globoturborotalita pseudopraebulloides, Sample B; (6a, 6b, 6c) NHMUK PM PF 75218 Globoturborotalita pseudopraebulloides, Sample B; (7) NHMUK PM PF 75220 Globoturborotalita pseudopraebulloides, Sample A; (8a, 8b, 8c) NHMUK PM PF 75221 Globoturborotalita pseudopraebulloides, Sample A; (9) NHMUK PM PF 75247 Globoturborotalita pseudopraebulloides, Sample A. Scale bars: (1)-(6b), (7)-(9) $=100 \mu \mathrm{m} ;(\mathbf{6 c})=10 \mu \mathrm{m}$. 


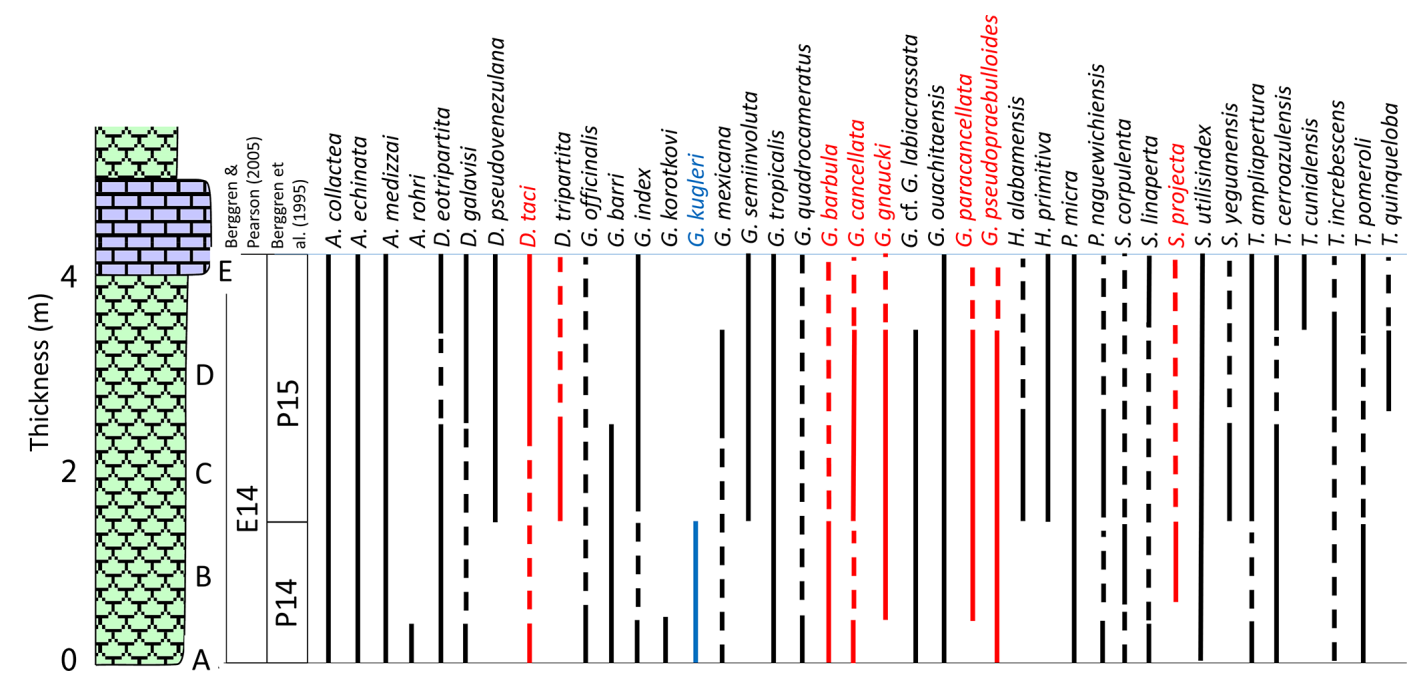

Figure 10. Stratigraphic section, planktonic foraminifera biostratigraphy and range chart of species recorded in the Rashrashiyah Formation. Taxa with earlier stratigraphic ranges than previously reported are in red; later stratigraphic occurrences are in blue. Solid line indicates species was found in the associated sample, and dashed lines are used when the species was not found in the sample but assumed to continue based on evidence from elsewhere (e.g., Pearson et al., 2006; Wade et al., 2018a). Legend for lithologies as in Fig. 3.

\section{Discussion}

\subsection{Preservation}

Four criteria were presented by Pearson and Burgess (2008) for distinguishing foraminifera tests that are not significantly recrystallized: (1) tests should be glassy or translucent in reflected light; (2) ultrafine features such as spines (if initially possessed) should survive; (3) smooth parts of the test such as the apertural lips, sutures, outer surface (in some species) and inner surface (in most species) should appear smooth at the submicron scale in high-resolution SEM images; and (4) in cross section the submicron microgranular texture of the wall (if originally possessed) should be clear when the test is broken.

Test preservation is very good in Sample A, specimens are glassy beneath the light microscope and spines are preserved on Globigerinatheka, satisfying the criteria for excellent preservation of Pearson and Burgess (2008). In Samples $\mathrm{B}$ and $\mathrm{D}$, the preservation is good, with specimens translucent under the light microscope. Moderate preservation is recorded for Samples C and E, with some infilling, encrustation and fragmentation (Figs. 4-9). Preservation is superior to other sections in this region (e.g., Ramadan et al., 2021).

\subsection{Biostratigraphy}

The planktonic foraminiferal assemblage indicates that all samples are of Priabonian age. No Morozovelloides or large Acarinina were found (except a singular dwarfed A. rohri in Sample A), indicating that all samples are above the middlelate Eocene turnover (MLET; Kamikuri and Wade, 2012; Wade et al., 2012). The extinction of M. crassatus marks the base of the Globigerinatheka semiinvoluta HOZ Zone (Zone E14) (Berggren and Pearson, 2005; Wade et al., 2011). The top (T) M. crassatus occurs within Chron C17n.3n and is calibrated to $38.073 \pm 0.005 \mathrm{Ma}$ at the Varignano section in Italy (Luciani et al., 2020) based on the Pälike et al. (2006) magnetochronology. This converts to $38.0 \mathrm{Ma}$ on the Westerhold et al. (2014) magnetochronology, which is the current standard used in the most recent edition of the Geologic Time Scale (GTS2020; Speijer et al., 2020). The entire section studied is therefore younger than $38 \mathrm{Ma}$.

We found a singular dwarfed specimen of Acarinina rohri in Sample A (Table 1). In the western North Atlantic (ODP Site 1052) a reduction in specimen size of Morozovelloides crassatus from 500 to $350 \mu \mathrm{m}$ was recorded during the MLET, due to photosymbiont bleaching and environmental stress (Wade et al., 2008; Wade and Olsson, 2009). Small $<250 \mu \mathrm{m}$ specimens of Acarinina consisting of A. collactea, A. echinata and A. medizzai are found in all samples (Fig. 4). Small acarininids have been shown to range beyond the MLET and into the Oligocene (Berggren et al., 2006; Wade and Hernitz Kucenjak, 2018; Luciani et al., 2020), though they are not consistently present in late Eocene samples from Jordan (Farouk et al., 2015).

Globigerinatheka is common, with specimens of G. barri, G. index, G. korotkovi, G. kugleri, G. mexicana, G. semiinvoluta, and G. tropicalis (Premoli Silva et al., 2006). Globigerinatheka semiinvoluta is present in samples C, D and E but absent from samples A and B. The Base (B) G. semiinvoluta is a secondary bioevent within Zone E14 but was previously used as a primary bioevent to mark the base of Zone P15 (Berggren et al., 1995). It has been calibrated to Chron C17n in several sections including ODP Site 1052 


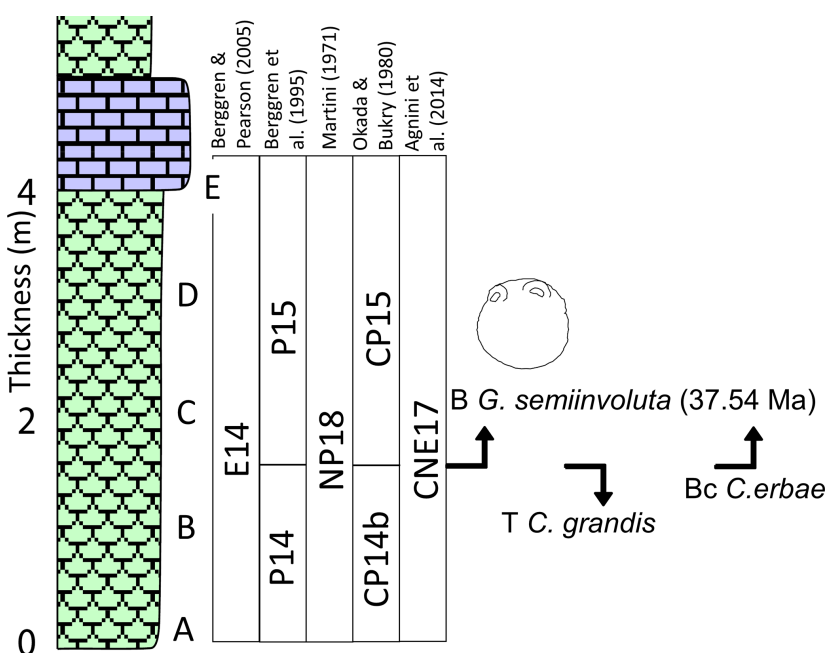

Figure 11. Section $\log$ of the upper Eocene Rashrashiyah Formation with planktonic foraminifera and calcareous nannofossil zonal schemes and bioevents. Drawing of G. semiinvoluta from Wade (2004). Legend for lithologies as in Fig. 3.

(Wade, 2004; Wade et al., 2012), Varignano (Luciani et al., 2020) and Alano (Agnini et al., 2021). At the Varignano section, B G. semiinvoluta is calibrated to Chron C17n.2n with an age of $37.665 \pm 0.006 \mathrm{Ma}$ (timescale of Pälike et al., 2006) (Luciani et al., 2020), which converts to $37.54 \mathrm{Ma}$ on Westerhold et al. (2014) magnetochronology (Fig. 11). The lack of G. semiinvoluta in Samples A and B raises the possibility that these samples could be from the short stratigraphic interval between the T M. crassatus and the B G. semiinvoluta. This interval was designated the Turborotalia pseudoampliapertura Zone by Haggag (1990) and has been recognized in several sections worldwide (Canudo and Molina, 1992; Wade, 2004; Agnini et al., 2011; Strougo et al., 2013). The B G. semiinvoluta may be diachronous, as the duration of the interval between T M. crassatus and B G. semiinvoluta is only $20 \mathrm{kyr}$ at ODP Site 1052 (Wade, 2004; Wade et al., 2012), $330 \mathrm{kyr}$ at Alano and $408 \mathrm{kyr}$ at the Varignano section (Luciani et al., 2020). Note, however, the discrepancy could be due to the criteria used to separate G. semiinvoluta from its ancestor G. mexicana (Premoli Silva et al., 2006). Thus the bioevent may be isochronous, but independent workers have not been unified in the discrimination of the first true G. semiinvoluta morphospecies.

$\mathrm{T}$ Planorotalites capdevilensis is slightly older than B $G$. semiinvoluta in the Italian sections of Alano (Agnini et al., 2011) and Varignano (Luciani et al., 2020). Wade (2004) found a longer range of $P$. capdevilensis from ODP Site 1052, western North Atlantic. P. capdevilensis was not found in this study of the Rashrashiyah Formation.

The characteristics of the assemblage are very consistent with stratigraphic equivalent sections studied in the Adriatic, Egypt and Armenia (Wade et al., 2012; Strougo et al., 2013; Cotton et al., 2017; Ramadan et al., 2021; Salama et al.,
2021). However, despite the high diversity, no Catapsydrax are present. This contrasts Adriatic cores where Catapsydrax increase in abundance at the base Priabonian (Wade et al., 2012). We record a high diversity of species belonging to Globoturborotalita (Figs. 8, 9 and 10), and G. pseudopraebulloides is unusually abundant (Fig. 9).

\subsection{Stratigraphic ranges}

The stratigraphic distribution of the recorded species is shown in Fig. 10. The stratigraphic ranges of many of the non-marker species are different to published schemes (e.g., Pearson et al., 2006; Aze et al., 2011; Wade et al., 2018a). Many species thought to have evolved in Zone E16 or Zone $\mathrm{O} 1$ are found at this section in Zone E14, suggesting their stratigraphic range needs revision. For example, Globoturborotalita barbula, Globoturborotalita pseudopraebulloides, Globoturborotalita paracancellata, Globoturborotalita cancellata, Globoturborotalita gnaucki and Subbotina projecta (Figs. 5, 8 and 9) were all thought to evolve between upper Eocene Zone E15 and lower Oligocene Zone O2 (Spezzaferri et al., 2018; Wade et al., 2018b, c). However, they are all present in Zone E14, with some species, for instance, Globoturborotalita pseudopraebulloides in high abundance (Fig. 9). The discrepancy between first occurrence in the published literature and this study is most likely due to the excellent preservation of this section coupled with the lack of recent taxonomic investigations on the late Eocene. Within the combined nannofossil and planktonic foraminifera assemblages, we do not see any evidence for reworking in these sediments as an explanation for the lower occurrences of certain species compared to their previously published stratigraphic ranges.

Dentoglobigerina is a diverse genus that evolved in the middle Eocene. We find and illustrate (Fig. 5.6 and 5.7) two specimens that we could not confidently place in any of the previously described species: we refer to these as Dentoglobigerina sp. 1 and Dentoglobigerina sp. 2, pending further investigations (see Appendix A for taxonomic notes). Many of the stratigraphic ranges presented in Pearson et al. (2006) have already been extended to older levels by Wade et al. (2018a) and Fayolle and Wade (2021). Dentoglobigerina eotripartita is present from the base sample (Sample A), confirming the stratigraphic range suggested in Wade et al. (2018a). Dentoglobigerina taci was thought to be confined to the Eocene-Oligocene boundary interval (Zone E16 to Zone O1) (Pearson and Wade, 2015; Wade et al., 2018a). Here we find Dentoglobigerina taci in Zone E14 (Figs. 5 and 10 ), extending its evolution to several million years earlier. We find a singular rare occurrence of D. tripartita in Sample C (Fig. 5.5).

Globigerinathekids are abundant in the samples. Premoli Silva et al. (2006) state that the extinction of G. barri occurs towards the end of Zone E14. Here we find G. barri in Samples A, B and C (Fig. 6), but not in the younger part of the 
section, potentially constraining the extinction of $G$. barri to early Zone E14. Our extinction horizon for G. barri is consistent with results from coeval Egyptian sections (Strougo et al., 2013). In Premoli Silva et al. (2006) the extinction of Globigerinatheka kugleri is given as Zone E13, but we find this species ranging higher (Zone E14).

Globoturborotalita is a long-ranging genus, from the Eocene to the present. Many species have been described, though their ranges, in general, are poorly constrained. Globoturborotalita barbula was previously only known from the Eocene-Oligocene boundary interval (Pearson and Wade, 2015; Spezzaferri et al., 2018). We find specimens in Samples A and B, suggesting this species evolved earlier than previously thought (Pearson and Wade, 2015; Spezzaferri et al., 2018). The stratigraphic range of $G$. cancellata is not well constrained, and until Spezzaferri et al. (2018) it had not been recorded outside of the Oligocene Globorotalia opima opima Zone, from which it was described. Spezzaferri et al. (2018) found and illustrated specimens from Zone $\mathrm{O} 1$ and suggested a questionable range from Zone E16 to Zone O5. We find and illustrate specimens from Zone E14 (Fig. 8), indicating that this species has a much longer stratigraphic range than previously suggested. G. paracancellata was described from the upper Oligocene, with recorded specimens occurring from the upper Eocene Zone E16 (Spezzaferri et al., 2018). Here we extend the stratigraphic range of $G$. paracancellata with specimens illustrated from Zone E14 (Fig. 9). G. gnaucki is abundant in Samples B, C and D (Table 1, Fig. 8). This species was thought to evolve in Zone E15 (Spezzaferri et al., 2018), but this study suggests it evolved in Zone E14 or older (Fig. 10). We find specimens that we refer to as Globoturborotalita cf. G. labiacrassata (Fig. 9). These have a higharched umbilical aperture and lobate profile but lack the thick rim boarding the aperture that is characteristic of this species. Our specimens are in Zone E14 and thus much older than the first appearance of G. labiacrassata (Zone O2) suggested by Spezzaferri et al. (2018). Further investigations are required to determine if these forms are a new species.

In Pearson et al. (2006) the evolution of Pseudohastigerina naguewichiensis from $P$. micra occurs at the base of Zone E15. We find and illustrate $P$. naguewichiensis in Zone E14 (Fig. 4). Our earlier evolution of this species is in agreement with Cotton et al. (2017), though an older range (Zone E13) is suggested by Strougo et al. (2013). The oldest previously recorded specimens of Subbotina projecta are from upper Eocene Zone E16. Here we document and illustrate specimens from Zone E14 (Table 1, Figs. 5 and 10). The occurrence of T. quinqueloba in Sample D (Figs. 8 and 10) confirms the stratigraphic range recorded in Pearson and Kučera (2018).

Despite the relatively good preservation and the high diversity of species recorded from the Rashrashiyah Formation (Table 1, Figs. 4-10), there are some species that were expected to be present, based on previous range chart compilations (e.g., Pearson et al., 2006; Aze et al., 2011), that were not found. These include Paragloborotalia griffinoides and $P$. nana, Chiloguembelina ototara, C. cubensis, and species of the genus Catapsydrax. However, we note that these species are recorded in upper Eocene sections from Egypt (Ramadan et al., 2021). We suspect that the absence of these taxa in the Rashrashiyah Formation is due to the environment, which is indicative of warm and oligotrophic conditions.

The amendment of planktonic foraminifera stratigraphic ranges has ramifications for the phylogenies and tropicalsubtropical diversity charts. The range charts presented in Pearson et al. (2006), Wade et al. (2018a), incorporated into Time-Scale Creator (Fordham et al., 2018), and the Mikrotax online portal (Huber et al., 2016) will require revision. Many species evolved earlier than previously thought, particularly within the Globoturborotalita genus. The extensions of the range of Pseudohastigerina naguewichiensis and Turborotalita quinqueloba were already suggested in Cotton et al. (2017) and confirmed here. Our study implies that the late Eocene tropical-subtropical diversity is higher than previously suggested in compilations (Ezard et al., 2011; Fraass et al., 2015; Lowery et al., 2020). Many of the species found in this study of the late Eocene extend through the EoceneOligocene transition and into the Oligocene, suggesting that the rate of turnover at the Eocene-Oligocene transition is not as large as previously thought and requires re-investigation.

\subsection{Integrated calcareous biostratigraphy}

The calcareous nannofossil assemblages were studied by Aljahdali et al. (2020) indicating that the section corresponds to Zone CNE17 of Agnini et al. (2014) and Zone NP18 of Martini (1971). The section is Priabonian age (upper Eocene), as indicated by the presence of Chiasmolithus oamaruensis. The T C. grandis between Samples B and C allows identification of the base Zone CP15 of Okada and Bukry (1980). The base common $(\mathrm{Bc})$ of Cribrocentrum erbae also occurs between Samples B and C. Throughout the section C. erbae increases in abundance consist with Zone CNE17 of Agnini et al. (2014). A single specimen of Isthmolithus recurvus was documented in Sample E (Aljahdali et al., 2020); however, this is not used in the biostratigraphic interpretation. The planktonic foraminifera biostratigraphy is consistent with the calcareous nannofossil biostratigraphy and can also be compared to other integrated calcareous biostratigraphic studies (e.g., Strougo et al., 2013; Farouk et al., 2015; Cotton et al., 2017; Luciani et al., 2020; Agnini et al., 2021).

The base of the Priabonian Global Stratotype Section and Point (GSSP) was recently defined by Agnini et al. (2021) at the Alano di Piave section (north-eastern Italy). The Bartonian-Priabonian boundary is placed at the prominent $14-16 \mathrm{~cm}$ crystal tuff layer known as the "Tiziano bed" at $63.57 \mathrm{~m}$. With our current $1 \mathrm{~m}$ sampling resolution and the three bioevents between Samples B and C, we are unable to confidently calculate sedimentation rates, but it would appear 
that the base of the section is either at, or very close to, the Bartonian-Priabonian boundary.

\section{Conclusions}

The planktonic foraminiferal biostratigraphy, integrated with calcareous nannofossil biostratigraphy, provides a robust stratigraphic framework for the Rashrashiyah Formation, indicating that the section is Priabonian (upper Eocene) in age. Planktonic foraminifera assemblages are diverse and extremely well-preserved. Our study reveals differing stratigraphic ranges to the ones established in the literature. Higher-resolution sampling will allow the horizons for Base G. semiinvoluta, Top C. grandis and Base Common C. erbae to be differentiated. Our study implies that the late Eocene tropical-subtropical diversity is likely to be higher than previously suggested in data compilations.

\section{Appendix A: Taxonomic list of species in this study}

Acarinina collactea (Finlay).

Acarinina echinata (Bolli), Fig. 4.1.

Acarinina medizzai (Toumarkine and Bolli), Fig. 4.2-4.6.

Acarinina rohri (Brönnimann and Bermúdez).

Dentoglobigerina eotripartita Pearson, Wade, and

Olsson, Fig. 5.1.

Dentoglobigerina galavisi (Bermúdez), Fig. 5.2.

Dentoglobigerina pseudovenezuelana

(Blow and Banner).

Dentoglobigerina taci Pearson and Wade, Fig. 5.3 and 5.4 .

Dentoglobigerina tripartita (Koch), Fig. 5.5.

Dentoglobigerina sp. 1, Fig. 5.7. This specimen has a dentoglobigerinid wall texture, a compressed final chamber and pronounced tooth.

Dentoglobigerina sp. 2, Fig. 5.6. This specimen has incised umbilical sutures and a compressed final chamber. In umbilical view this specimen bears a close morphological resemblance to the drawing of Globigerinatheka index by Postuma (1971). However, due to the wall texture and lack of supplementary apertures, we consider this specimen to belong within Dentoglobigerina, pending further investigations.

Globigerina officinalis Subbotina.

Globigerinatheka barri Brönnimann, Fig. 6.3 and 6.4.

Globigerinatheka index (Finlay), Fig. 6.5 and 6.6.

Globigerinatheka korotkovi (Keller).

Globigerinatheka kugleri (Bolli, Loeblich, and Tappan),

Fig. 6.7 and 6.8. Globigerinatheka mexicana (Cushman), Fig. 6.9 and 6.10 .

Globigerinatheka semiinvoluta (Keijzer), Fig. 7.4 and 7.5 .
Globigerinatheka tropicalis (Blow and Banner),

Fig. 7.1-7.3.

Globorotaloides quadrocameratus Olsson, Pearson, and Huber, Fig. 7.6.

Globoturborotalita barbula Pearson and Wade, Fig. 8.1 and 8.2 .

Globoturborotalita cancellata (Pessagno), Fig. 8.3-8.5. Globoturborotalita gnaucki (Blow and Banner), Fig. 8.6. Globoturborotalita cf. G. labiacrassata (Jenkins),

Fig. 9.1 and 9.2. These specimens have a high-arched umbilical aperture and lobate profile but lack the thick rim boarding the aperture that is characteristic of G. labiacrassata.

Globoturborotalita ouachitaensis (Howe and Wallace), Fig. 8.7 and 8.8 .

Globoturborotalita paracancellata Olsson and

Hemleben, Fig. 9.3 and 9.4.

Globoturborotalita pseudopraebulloides Olsson and

Hemleben, Fig. 9.5-9.9.

Hantkenina alabamensis Cushman.

Hantkenina primitiva Cushman and Jarvis, Fig. 6.2.

Pseudohastigerina micra (Cole), Fig. 4.9-4.12.

Pseudohastigerina naguewichiensis (Myatliuk), Fig. 4.7 and 4.8 .

Subbotina corpulenta (Subbotina), Fig. 6.1.

Subbotina linaperta (Finlay).

Subbotina projecta Olsson, Pearson, and Wade, Fig. 5.8.

Subbotina utilisindex Jenkins and Orr, Fig. 5.9 and 5.10.

Subbotina yeguanensis (Weinzierl and Applin).

Turborotalia ampliapertura (Bolli), Fig. 7.7.

Turborotalia cerroazulensis (Cole), Fig. 7.8-7.10.

Turborotalia cunialensis (Toumarkine and Bolli).

Turborotalia increbescens (Bandy).

Turborotalia pomeroli (Toumarkine and Bolli).

Turborotalita quinqueloba (Natland), Fig. 8.9.

Data availability. The data generated in this study are included within the paper and in Table 1. Imaged specimens are deposited at the Natural History Museum, London, UK.

Author contributions. BW conducted the analyses and wrote the paper. MA conceived the project and the prepared lithographic logs. MA, YM, AM, SA and IZ conducted fieldwork, sampled the studied section and provided comments to manuscript text and figures.

Competing interests. The authors declare that they have no conflict of interest.

Disclaimer. Publisher's note: Copernicus Publications remains neutral with regard to jurisdictional claims in published maps and institutional affiliations. 
Acknowledgements. We are extremely grateful to $\mathrm{Na}$ talie Cheng, who conducted the light and SEM imaging, prepared the plates and assisted in taxonomic discussion, and to Marcin Latas, who assisted with sample preparation and the map. Comments on an earlier version of the manuscript were provided by Paul Pearson, Florent Fayolle and Alessio Fabbrini. We thank the CEO of the Saudi Geological Survey Eng. Abdullah M. AlShamrani and vice president Saleh Al-Sefry, Nasser Aljahdali and Wadee Kashghari for supporting fieldwork, permission to use SGS labs and equipment for this work. We thank Helen Coxall and an anonymous reviewer for their constructive suggestions. This paper was edited by Kirsty Edgar, who provided additional insights and comments that improved the manuscript.

Financial support. Bridget S. Wade was supported by UK Natural Environment Research Council (NERC) reference number NE/G014817.

Review statement. This paper was edited by Kirsty Edgar and reviewed by Helen Coxall and one anonymous referee.

\section{References}

Agnini, C., Fornaciari, E., Giusberti, L., Grandesso, P., Lanci, L., Luciani, V., Muttoni, G., Palike, H., Rio, D., Spofforth, D. J. A., and Stefani, C.: Integrated biomagnetostratigraphy of the Alano section (NE Italy): A proposal for defining the middle-late Eocene boundary, Geol. Soc. Am. B., 123, 841-872, 2011.

Agnini, C., Fornaciari, E., Raffi, I., Catanzariti, R., Pälike, H., Backman, J., and Rio, D.: Biozonation and biochronology of Paleogene calcareous nannofossils from low and middle latitudes, Newsl. Stratigr., 47, 131-181, 2014.

Agnini, C., Backman, J., Boscolo-Galazzo, F., Condon, D. J., Fornaciari, E., Galeotti, S., Giusberti, L., Grandesso, P., Lanci, L., Luciani, V., Monechi, S., Muttoni, G., Pälike, H., Pampaloni, M. L., Papazzoni, C. A., Pearson, P. N., Pignatti, J., Premoli Silva, I., Raffi, I., Rio, D., Rook, L., Sahy, D., Spofforth, D. J. A., Stefani, C., and Wade, B. S.: Proposal for the Global Boundary Stratotype Section and Point (GSSP) for the Priabonian Stage (Eocene) at the Alano section (Italy), Episodes, 44, 151-173, 2021.

Aljahdali, M. H., Elhag, M., Mufrreh, Y., Memesh, A., AlSoubhi, S., and Zalmout, I. S.: Upper Eocene calcareous nannofossil biostratigraphy: a new preliminary Priabonian record from northern Saudi Arabia, Appl. Ecol. Environ. Res., 18, 5607-5625, https://doi.org/10.15666/aeer/1804_56075625, 2020.

Al-Rawi, M. M.: Petroleum systems in Jordan, GEO ExPro, 11, 1, available at: https://archives.datapages.com/data/ geo-expro-magazine/011/011001/pdfs/22.htm (last access: 26 September 2021), 2014.

Aze, T., Ezard, T. H. G., Purvis, A., Coxall, H. K., Stewart, D. R. M., Wade, B. S., and Pearson, P. N.: A phylogeny of Cenozoic macroperforate planktonic foraminifera from fossil data, Biol. Rev., 86, 900-927, 2011.

Berggren, W. A. and Pearson, P. N.: A revised tropical to subtropical planktonic foraminiferal zonation of the Eocene and Oligocene, J. Foramin. Res., 35, 279-298, 2005.
Berggren, W. A., Kent, D. V., Swisher III, C. C., and Aubry, M.-P.: A Revised Cenozoic Geochronology and Chronostratigraphy, in: Geochronology, Time Scales and Global Stratigraphic Correlation, edited by: Berggren, W. A., Kent, D. V., Aubry, M.-P., and Hardenbol, J., SEPM Society for Sedimentary Geology, Tulsa, OK, USA, 1995.

Berggren, W. A., Pearson, P. N., Huber, B. T., and Wade, B. S.: Taxonomy, Biostratigraphy and Phylogeny of Eocene Acarinina, in: Atlas of Eocene Planktonic Foraminifera, edited by: Pearson, P. N., Olsson, R. K., Huber, B. T., Hemleben, C., and Berggren, W. A., Cushman Foundation Special Publication, 41, 257-326, 2006.

Bown, P. R., Dunkley Jones, T., Lees, J. A., Randell, R. D., Mizzi, J. A., Pearson, P. N., Coxall, H. K., Young, J. R., Nicholas, C. J., Karega, A., Singano, J., and Wade, B. S.: A Paleogene calcareous microfossil Konservat-Lagerstätte from the Kilwa Group of coastal Tanzania, Geol. Soc. Am. Bull., 120, 3-12, 2008.

Canudo, J. I. and Molina, E.: Bioestratigrafía con foraminíferos planctónicos del Paleógeno del Pirineo. in h. Luterbacher (edn.), Neues Jahrbuch für Geologie und Paläontologie, Abhandlungen, 186, 97-135, 1992.

Cotton, L. J., Zakrevskaya, E. Y., van der Boon, A., Asatryan, G., Hayrapetyan, F., Israyelyan, A., Krijgsman, W., Less, G., Monechi, S., Papazzoni, C. A., Pearson, P. N., Razumovskiy, A., Renema, W., Shcherbinina, E., and Wade, B S.: Integrated stratigraphy of the Priabonian (upper Eocene) Urtsadzor section, Armenia, Newsl. Stratigr., 50, 269-295, https://doi.org/10.1127/nos/2016/0313, 2017.

Dunkley Jones, T., Bown, P. R., Pearson, P. N., Wade, B. S., Coxall, H. K., and Lear, C. H.: Major shifts in calcareous phytoplankton assemblages through the EoceneOligocene transition of Tanzania and their implications for lowlatitude primary production, Paleoceanography, 23, PA4204, https://doi.org/10.1029/2008PA001640, 2008.

Ezard, T. H. G., Aze, T., Pearson, P. N., and Purvis, A.: Interplay between changing climate and species' ecology drives macroevolutionary dynamics, Science, 332, 349-351, 2011.

Farouk, S., Faris, M., Ahmad, F., and Powell, J. H.: New microplanktonic biostratigraphy and depositional sequences across the Middle-Late Eocene and Oligocene boundaries in eastern Jordan, GeoArabia - Middle East Petroleum Geosciences, 20, 145-172, 2015.

Fayolle, F. and Wade, B. S.: The evolution of Eocene planktonic foraminifera Dentoglobigerina, J. Syst. Palaeontol., 19, 333376, 2021.

Firth, J. V., Eldrett, J. S., Harding, I. C., Coxall, H. K., and Wade, B. S.: Integrated biomagnetochronology for the Palaeogene of ODP Hole 647A: implications for correlating palaeoceanographic events from high to low latitudes, in: Magnetic Methods and the Timing of Geological Processes, edited by: Jovane, L., Herrero-Bervera, E., Hinnov, L. A., and Housen, B. A., Geological Society, London, Special Publications, 373, 29-78, 2013.

Fordham, B. G., Aze, T., Haller, C., Zehady, A. K., Pearson, P. N., Ogg, J. G., and Wade, B. S.: Future-proofing the Cenozoic macroperforate planktonic foraminifera phylogeny of Aze \& others (2011), PLoS ONE, 13, e0204625, https://doi.org/10.1371/journal.pone.0204625, 2018. 
Fraass, A. J., Kelly, D. C., and Peters, S. E.: Macroevolutionary history of the planktic foraminifera, Annu. Rev. Earth Planet. Sc., 43, 139-166, https://doi.org/10.1146/annurev-earth-060614105059, 2015.

Guiraud, R., Issawi, B., and Bosworth, W.: Phanerozoic history of Egypt and surrounding areas, Peri-Tethys Memoir, 6, 469-509, 2001.

Haggag, M. A.: Globigerina pseudoampliapertura Zone, a new late Eocene planktonic foraminiferal zone (Fayoum area, Egypt), Neues Jahrbuch für Geologie und Paläontologie, Monatshefte, Stuttgart, 295-307, 1990.

Halawani, M.: Stratigraphic column for the Phanerozoic rocks of Saudi Arabia. A compilation and synthesis with comments Saudi Geological Survey Technical Reports, Kingdom of Saudi Arabia SGS-TR-2001-3 2001, 2001.

Hemleben, C. and Olsson, R. K.: Wall textures of Eocene planktonic foraminifera, in: Atlas of Eocene Planktonic Foraminifera, edited by: Pearson, P. N., Olsson, R. K., Huber, B. T., Hemleben, C., and Berggren, W. A., Cushman Foundation Special Publication, 41, 47-66, Allen Press, Lawrence, KS, USA, 2006.

Huber, B. T., Petrizzo, M. R., Young, J., Falzoni, F., Gilardoni, S., Bown, P. R., and Wade, B. S.: Pforams@mikrotax: A new online taxonomic database for planktonic foraminifera, Micropalaeontology, 62, 429-438, 2016.

Kamikuri, S. and Wade, B. S.: Radiolarian magnetobiochronology and faunal turnover across the middle/late Eocene boundary at Ocean Drilling Program Site 1052 in the western North Atlantic Ocean, Mar. Micropaleontol., 88-89, 41-53, 2012.

Lear, C., Bailey, T. R., Pearson, P. N., Coxall, H. K., and Rosenthal, Y.: Cooling and ice growth across the Eocene - Oligocene transition, Geology, 36, 251-254, 2008.

Lowery, C. M., Bown, P. R., Fraass, A. J., and Hull, P. M.: Ecological response of plankton to environmental change: thresholds for extinction, Annu. Rev. Earth Planet. Sc., 48, 403-429, 2020.

Luciani, V., Fornaciari, E., Papazzoni, C. A., Dallanave, E., Giusberti, L., Stefani, C., and Amante, E.: Integrated stratigraphy at the Bartonian-Priabonian transition: correlation between shallow benthic and calcareous plankton zones (Varignano section, northern Italy), Geol. Soc. Am. Bull., 132, 495-520, 2020.

Martini, E.: Standard Tertiary and Quaternary calcareous nannoplankton zonation. Proc. II Planktonic Conference, Roma, 1970, Tecnoscienza, Roma, 1971.

Meissner, C. R., Griffin Jr., M. B., Riddler, G. P., Marcel Van Eck, Aspinall, N. C., Farasani, A. M., and Dini, S. M.: Preliminary Geologic Map of the Thaniyat Turayf Quadrangle, Sheet 29c, Kingdom of Saudi Arabia - Department of the Interior, US Geological Survey, Washington, DC, 1990.

Miller, K. G., Browning, J. V., Aubry, M.-P., Wade, B. S., Katz, M. E., Kulpecz, A. A., and Wright, J. D.: Eocene-Oligocene global climate and sea-level changes: St. Stephens Quarry, Alabama, Geol. Soc. Am. Bull., 120, 34-53, 2008.

Moore, T. C. and Kamikuri, S.: Data report: Radiolarian stratigraphy across the Eocene/Oligocene boundary in the equatorial Pacific, Sites 1218, U1333, and U1334, In: Proceedings IODP, vol. 320/321, Pälike et al., Integr. Ocean Drill. Program Management International, Inc., Tokyo, 2012.

Norris, R. D., Wilson, P. A., Blum, P., and the Expedition 342 Scientists: Proc. IODP, 342: College Station, TX (Integrated Ocean Drilling Program), College Station, TX, USA, 2014.
Okada, H. and Bukry, D.: Supplementary modification and introduction of code numbers to the low latitude coccolith biostratigraphic zonation (Bukry, 1973; 1975), Mar. Micropaleontol., 5, 321-325, 1980.

Pälike, H., Norris, R. D., Herrle, J. O., Wilson, P. A., Coxall, H. K., Lear, C. H., Shackleton, N. J., Tripati, A. K., and Wade, B. S.: The heartbeat of the Oligocene climate system, Science, 314, 1894-1898, 2006.

Pearson, P. N. and Burgess, C. E.: Foraminifer test preservation and diagenesis: comparison of high latitude Eocene sites, Geol. Soc. Lond. Spec. Publ., 303, 59-72, 2008.

Pearson, P. N. and Kučera, M.: Taxonomy, biostratigraphy, and phylogeny of Oligocene Turborotalita, in: Atlas of Oligocene Planktonic Foraminifera, edited by: Wade, B. S., Olsson, R. K., Pearson, P. N., Huber, B. T., and Berggren, W. A., Cushman Foundation of Foraminiferal Research, Special Publication, No. 46, 385-392, 2018.

Pearson, P. N. and Wade, B. S.: Systematic taxonomy of exceptionally well-preserved planktonic foraminifera from the Eocene/Oligocene boundary of Tanzania, Cushman Foundation for Foraminiferal Research Special Publication, No. 45, 1-85, Allen Press, Lawrence, KS, USA, 2015.

Pearson, P. N., Ditchfield, P. W., Singano, J., Harcourt-Brown, K. G., Nicholas, C. J., Olsson, R. N., Shackleton, N. J., and Hall, M. A.: Warm tropical sea surface temperatures in the Late Cretaceous and Eocene epochs, Nature, 413, 481-487, 2001.

Pearson, P. N., Olsson, R. K., Huber, B. T., Hemleben, C., and Berggren, W. A.: Atlas of Eocene planktonic foraminifera, Cushman Foundation for Foraminiferal Research Special Publication, 41, 513 pp., Allen Press, Lawrence, KS, USA, 2006.

Pearson, P. N., van Dongen, B. E., Nicholas, C. J., Pancost, R. D., Schouten, S., Singano, J. M., and Wade, B. S.: Stable warm tropical climate through the Eocene epoch, Geology, 35, 211-214, 2007.

Pearson, P. N., McMillan, I. K., Wade, B. S., Dunkley Jones, T., Coxall, H. K., Bown, P. R., and Lear, C. H.: Extinction and environmental change across the Eocene-Oligocene boundary in Tanzania, Geology, 36, 179-182, 2008.

Pearson, P. N., Foster, G. L., and Wade, B. S.: Atmospheric carbon dioxide through the Eocene-Oligocene climate transition, Nature, 461, 1110-1113, 2009.

Postuma, J. A.: Manual of planktonic foraminifera, Elsevier for Shell Group, The Hague, 406 pp., 1971.

Premoli Silva, I., Wade, B. S., and Pearson, P. N.: Taxonomy of Globigerinatheka and Orbulinoides, in: Atlas of Eocene Planktonic Foraminifera, edited by: Pearson, P. N., Olsson, R. K., Huber, B. T., Hemleben, C., and Berggren, W. A., Cushman Foundation Special Publication, 41, 169-212, Allen Press, Lawrence, KS, USA, 2006.

Ramadan, A. M., Abd El-Gaied, I. M., Saber, S. G., and Salama, Y. F.: Foraminiferal biostratigraphy and paleoenvironment evolution recorded in the Upper Eocene succession in northeastern Desert, Egypt, J. Sediment. Environ., 6, 485-512, 2021.

Salama, Y., Sayed, M., Saber, S., and Abd El-Gaied, I. M.: Eocene planktonic foraminifera from the north Eastern Desert, Egypt: Biostratigraphic, paleoenvironmental and sequence stratigraphy implications, Palaeontol. Electron., 24, a11, https://doi.org/10.26879/1088, 2021. 
Seilacher, A.: Begriff und Bedeutung der Fossil-Lagerstätten: Neues Jahrbuch für Geologie und Paläontologie, Monatshefte, 1, 34-39, 1970.

Speijer, R. P., Pälike, H., Hooker, J. J., and Ogg, J. G.: The Paleogene period, in: Geologic Time Scale 2020, edited by: Gradstein, F. M., Ogg, J. G., Schmitz, M. D., and Ogg, G. M., 1087-1140, Elsevier, Amsterdam, the Netherlands, 2020.

Spezzaferri, S., Olsson, R. K., Hemleben, Ch., Wade, B. S., and Coxall, H. K.: Taxonomy, biostratigraphy, and phylogeny of Oligocene and lower Miocene Globoturborotalita, in: Atlas of Oligocene Planktonic Foraminifera, edited by: Wade, B. S., Olsson, R. K., Pearson, P. N., Huber, B. T., and Berggren, W. A., Cushman Foundation of Foraminiferal Research, Special Publication, No. 46, 231-268, Allen Press, Lawrence, KS, USA, 2018.

Strougo, A., Faris, M., Haggag, M. A. Y., Abul-Nasr, R. A., and Gingerich, P. D.: Planktonic Foraminifera and calcareous nannofossil biostratigraphy through the Middle to Late Eocene transition at Wadi Hitan, Fayum Province, Egypt, Contributions from the Museum of Paleontology, University of Michigan, 32, 111138, 2013

Wade, B. S.: Planktonic foraminiferal biostratigraphy and mechanisms in the extinction of Morozovella in the late Middle Eocene, Mar. Micropaleontol., 51, 23-38, 2004.

Wade, B. S. and Hernitz Kucenjak, M.: Taxonomy, biostratigraphy, and phylogeny of Oligocene Acarinina, in: Atlas of Oligocene Planktonic Foraminifera, edited by: Wade, B. S., Olsson, R. K., Pearson, P. N., Huber, B. T., and Berggren, W. A., Cushman Foundation of Foraminiferal Research, Special Publication, No. 46, 393-402, Allen Press, Lawrence, KS, USA, 2018.

Wade, B. S. and Pearson, P. N.: Planktonic foraminiferal turnover, diversity fluctuations and geochemical signals across the Eocene/Oligocene boundary in Tanzania, Mar. Micropaleontol., 68, 244-255, 2008.

Wade, B. S. and Olsson, R. K.: Investigation of pre-extinction dwarfing in Cenozoic planktonic foraminifera, Palaeogeogr. Palaeocl., 284, 39-46, 2009.

Wade, B. S., Al-Sabouni, N., Hemleben, C., and Kroon, D.: Symbiont bleaching in fossil planktonic foraminifera, Evol. Ecol., 22, 253-265, 2008.
Wade, B. S., Pearson, P. N., Berggren, W. A., and Pälike, H.: Review and revision of Cenozoic tropical planktonic foraminiferal biostratigraphy and calibration to the geomagnetic polarity and astronomical time scale, Earth Sci. Rev., 104, 111-142, 2011.

Wade, B. S., Premec-Fucek, V., Kamikuri, S., Bartol, M., Luciani, V., and Pearson, P. N.: Successive extinctions of muricate planktonic foraminifera (Morozovelloides and Acarinina) mark the base Priabonian, Newsl. Stratigr., 45, 245-262, https://doi.org/10.1127/0078-0421/2012/0023, 2012.

Wade, B. S., Olsson, R. K., Pearson, P. N., Huber, B. T., and Berggren, W. A. (Eds.): Atlas of Oligocene Planktonic Foraminifera, Cushman Foundation Special Publication, No. 46, 528 pp., Allen Press, Lawrence, KS, USA, 2018a.

Wade, B. S., Pearson, P. N., Olsson, R. K., Fraass, A. Leckie, R. M., and Hemleben, Ch.: Taxonomy, biostratigraphy, and phylogeny of Oligocene and lower Miocene Dentoglobigerina and Globoquadrina, in: Atlas of Oligocene Planktonic Foraminifera, edited by: Wade, B. S., Olsson, R. K., Pearson, P. N., Huber, B. T., and Berggren, W. A., Cushman Foundation of Foraminiferal Research, Special Publication, No. 46, 331-384, 2018 b.

Wade, B. S., Olsson, R. K., Pearson, P. N., Edgar, K. M., and Premoli Silva, I.: Taxonomy, biostratigraphy, and phylogeny of Oligocene Subbotina, in: Atlas of Oligocene Planktonic Foraminifera, edited by: Wade, B. S., Olsson, R. K., Pearson, P. N., Huber, B. T., and Berggren, W. A., Cushman Foundation of Foraminiferal Research, Special Publication, No. 46, 307-330, Allen Press, Lawrence, KS, USA, 2018 c.

Wallace, C. A., Dini, S. M., and Al-Farasani, A. N.: Geological map of part of the Turayf Quadrangle, Sheet 31C, and An Nabk Quadrangle, Sheet 31B, Kingdom of Saudi Arabia, Ministry of Petroleum and Mineral resources, Saudi Geological Survey, Geoscience Map Series GM-125C, 1994.

Westerhold, T., Röhl, U., Pälike, H., Wilkens, R., Wilson, P. A., and Acton, G.: Orbitally tuned timescale and astronomical forcing in the middle Eocene to early Oligocene, Clim. Past, 10, 955-973, https://doi.org/10.5194/cp-10-955-2014, 2014. 